\title{
The expression and role of protein kinase C (PKC) epsilon in clear cell renal cell carcinoma
}

\author{
Bin Huang ${ }^{1 \dagger}$, Kaiyuan $\mathrm{Cao}^{2 \dagger}$, Xiubo $\mathrm{Li}^{3}$, Shengjie Guo ${ }^{4}$, Xiaopeng Mao ${ }^{1}$, Zhu Wang $^{2}$, Jintao Zhuang ${ }^{1}$, \\ Jincheng Pan ${ }^{1}$, Chengqiang Mo ${ }^{1}$, Junxing Chen ${ }^{1 *}$ and Shaopeng Qiu ${ }^{1 *}$
}

\begin{abstract}
Protein kinase C epsilon (PKC $\varepsilon$ ), an oncogene overexpressed in several human cancers, is involved in cell proliferation, migration, invasion, and survival. However, its roles in clear cell renal cell carcinoma (RCC) are unclear. This study aimed to investigate the functions of PKC $\varepsilon$ in RCC, especially in clear cell RCC, to determine the possibility of using it as a therapeutic target. By immunohistochemistry, we found that the expression of PKC $\varepsilon$ was up-regulated in RCCs and was associated with tumor Fuhrman grade and T stage in clear cell RCCs. Clone formation, wound healing, and Borden assays showed that down-regulating PKC $\varepsilon$ by RNA interference resulted in inhibition of the growth, migration, and invasion of clear cell RCC cell line 769P and, more importantly, sensitized cells to chemotherapeutic drugs as indicated by enhanced activity of caspase-3 in PKC $\varepsilon$ siRNA-transfected cells. These results indicate that the overexpression of PKC $\varepsilon$ is associated with an aggressive phenotype of clear cell RCC and may be a potential therapeutic target for this disease.
\end{abstract}

Keywords: Protein kinase C epsilon, Renal cell carcinoma, Clear cell

\section{Background}

Renal cell carcinoma (RCC) accounts for approximately $3 \%$ of all malignant tumors in adults, which afflicts about 58, 240 people and causes nearly 13, 040 deaths each year in USA [1]. RCCs are classified into five major subtypes: clear cell (the most important type, accounts for $82 \%$ ), papillary, chromophobe, collecting duct, and unclassified RCC [2]. Operation is the first treatment choice for RCC; however, some patients already have metastasis at the time of diagnosis and are resistant to conventional chemotherapy, radiotherapy, and immunotherapy [3]. Thus, a more effective anti-tumor therapy is urgently needed.

Protein kinase C (PKC), a family of phospholipiddependent serine/threonine kinases, plays an important role in intracellular signaling in cancer [4-8]. To date, at least 11 PKC family members have been identified. PKC isoenzymes can be categorized into three groups by their structural and biochemical properties: the

\footnotetext{
* Correspondence: junxingchen@hotmail.com; qiusp2009@live.cn

+ Contributed equally

'Department of Urology, the First Affiliated Hospital, Sun Yat-Sen University, Guangzhou (510080), China

Full list of author information is available at the end of the article
}

conventional or classical ones $(\alpha, \beta \mathrm{I}, \beta \mathrm{II}$, and $\gamma$ ) require $\mathrm{Ca}^{2+}$ and diacylglycerol (DAG) for their activation; the novel ones $(\delta, \varepsilon, \eta$, and $\theta)$ are dependent on DAG but not $\mathrm{Ca}^{2+}$; the atypical ones $(\zeta$ and $\lambda / \mathrm{l})$ are independent of both $\mathrm{Ca}^{2+}$ and DAG [4-6]. Among them, PKC $\varepsilon$ is the only isoenzyme that has been considered as an oncogene which regulates cancer cell proliferation, migration, invasion, chemo-resistance, and differentiation via the cell signaling network by interacting with three major factors RhoA/C, Stat3, and Akt [9-13]. PKCE is overexpressed in many types of cancer, including bladder cancer [14], prostate cancer [15], breast cancer [16], head and neck squamous cell carcinoma [17], and lung cancer $[18]$ as well as RCC cell lines $[19,20]$. The overexpression and functions of PKCE imply its potential as a therapeutic target of cancer.

In this study, we detected the expression of PKC $\varepsilon$ in 128 human primary RCC tissues and 15 normal tissues and found that $\mathrm{PKC \varepsilon}$ expression was up-regulated in these tumors and correlated with tumor grade. Furthermore, PKC $\varepsilon$ regulated cell proliferation, colony formation, invasion, migration, and chemo-resistance of clear cell RCC cells. Those results suggest that PKCE is

\section{Biomed Central}


crucial for survival of clear cell RCC cells and may serve as a therapeutic target of RCC.

\section{Methods \\ Samples}

We collected 128 specimens of resected RCC and 15 specimens of pericancerous normal renal tissues from the First Affiliated Hospital of the Sun Yat-sen University (Guangzhou, China). All RCC patients were treated by radical nephrectomy or partial resection. Of the 128 RCC samples, 10 were papillary RCC, 10 were chromophobe RCC, and 108 were clear cell RCC according to the 2002 AJCC/UICC classification. The clear cell RCC samples were from 69 male patients and 39 female patients at a median age of 56.5 years (range, 30 to 81 years). Tumors were staged according to the 2002 TNM staging system [21] and graded according to the Fuhrman four-grade system [22]. Informed consent was obtained from all patients to allow the use of samples and clinical data for investigation. This study was approved by the Ethics Council of the Sun Yat-sen University for Approval of Research Involving Human Subjects.

\section{Cell culture}

Five human RCC cell lines 769P, 786-O, OS-RC-2, SN12C, and SKRC39 were used in this research. Clear cell RCC cell lines 769P and 786-O were purchased from the American Type Culture Collection (Rockville, MD); RCC cell lines OS-RC-2, SN12C, and SKRC39 were a kind gift from Dr. Zhuowei Liu (Department of Urology, Sun Yat-sen University Cancer Center). 769P, 786-O, OS-RC-2, and SKRC39 cells were cultured in RPMI-1640 (Gibco, Carlsbad, California); SN12C cells were maintained in Dulbeccos's modified Eagle's medium (DMEM, Gibco) containing 10\% fetal calf serum (FCS, Gibco, Carlsbad, California), 1\% (v/v) penicillin, and $100 \mu \mathrm{g} / \mathrm{ml}$ streptomycin at $37^{\circ} \mathrm{C}$ in a $5 \% \mathrm{CO}_{2}$ atmosphere.

\section{Immunohistochemistry and scoring for PKC $\varepsilon$ expression}

All 5- $\mu \mathrm{m}$ thick paraffin sections of tissue samples were deparaffinized with xylene and rehydrated through graded alcohol washes, followed by antigen retrieval by heating sections in sodium citrate buffer $(10 \mathrm{mM}, \mathrm{pH}$ 6.0) for $30 \mathrm{~min}$. Endogenous peroxidase activity was blocked with 30 min incubation in methanol containing $0.03 \% \mathrm{H}_{2} \mathrm{O}_{2}$. The slides were then incubated in PBS $(\mathrm{pH}$ 7.4) containing normal goat serum (dilution 1:10) and subsequently incubated with monoclonal mouse IgG1 anti-PKC $\varepsilon$ antibody (610085; BD Biosciences, BD, Franklin Lakes, NJ USA) with 1:200 dilution at $4^{\circ} \mathrm{C}$ overnight. Following this step, slides were treated with biotinlabeled anti-IgG and incubated with avidin-biotin peroxidase complex. Reaction products were visualized by diaminobenzidine (DAB) staining and Meyer's hematoxylin counterstaining. Negative controls were prepared by replacing the primary antibody with mouse IgG1 (I1904-79G, Stratech Scientific Ltd, UK). Phosphate-buffered saline instead of primary antibody was used for blank controls.

Three independent pathologists blinded to clinical data scored PKCE immunohistochemical staining of all sections according to staining intensity and the percentage of positive tumor cells as follows $[23,24]$ : no staining scored 0 ; faint or moderate staining in $\leq 25 \%$ of tumor cells scored 1 ; moderate or strong staining in $25 \%$ to $50 \%$ of tumor cells scored 2; strong staining in $\geq 50 \%$ of tumor cells scored 3 . For each section, 10 randomly selected areas were observed under high magnification and 100 tumor cells in each area were counted to calculate the proportion of positive cells. Overexpression of $\mathrm{PKC} \varepsilon$ was defined as staining index $\geq 2$. Immunohistochemical reactions for all samples were repeated at least three times and typical results were illustrated.

\section{Western blot analysis for PKC $\varepsilon$ expression}

The expression of PKCE in 769P, 786-O, OS-RC-2, SN12C, and SKRC39 cells was detected by Western blot as described previously [25]. Briefly, total proteins were extracted from RCC cell lines and denatured in sodium dodecyl sulfate (SDS) sample buffer, then equally loaded onto $10 \%$ polyacrylamide gel. After electrophoresis, the proteins were transferred to a polyvinylidene difluoride membrane. Blots were incubated with the indicated primary antibodies overnight at $4^{\circ} \mathrm{C}$ and detected with horseradish peroxidase-conjugated secondary antibody. The monoclonal anti-PKC $\varepsilon$ antibody was used at the dilution of 1:3, 000, whereas anti-GAPDH (sc-137179; Santa Cruz Biotechnology, Santa Cruz, CA, USA) was used at the dilution of 1:2, 000 .

\section{Immunocytochemistry for PKC $\varepsilon$ expression and location} $769 \mathrm{P}$ cells were washed with $1 \times$ PBS and fixed in $4 \%$ paraformaldehyde for $10 \mathrm{~min}$ at room temperature, blocked in $0.1 \%$ PBS-Tween solution containing 5\% donkey serum $(v / v)$ at room temperature for $1 \mathrm{~h}$, and incubated overnight with anti-PKC $\varepsilon$ antibody (1:300) in blocking solution. Then cells were washed three times for 10 min with $0.1 \%$ PBS-Tween and incubated for $1 \mathrm{~h}$ with secondary antibody in blocking solution. DyLight488-conjugated AffiniPure donkey anti-mouse $\operatorname{IgG}(\mathrm{H}+\mathrm{L})$ was used at the dilution of 1:500 (715485151, Jackson ImmunoResearch Europe, Newmarket, Suffolk, UK). After incubation, cells were washed three times with $0.1 \%$ PBS-Tween, counterstained with Hoechst 33342, and mounted for confocal microscopy. 
The expression and location of PKCe in cells were observed under a fluorescent microscope.

RNA interference (RNAi) to knockdown PKC $\varepsilon$ in 769P cells As described in literature [26-28], 769P cells were transfected with small interfering RNA (siRNA) against PKC $\varepsilon$ (sc-36251) and negative control siRNA (sc-37007) by Lipofectamine 2000 transfection reagent and OptiMEMTM (Invitrogen, Carlsbad, CA, USA) according to the manufacturer's protocol. All siRNAs were obtained from Santa Cruz Biotechnology. Briefly, $1 \times 10^{5} 769 \mathrm{P}$ cells were plated in each well of 6-well plates and cultured to reach a $90 \%$ confluence. Cells were then transfected with siRNA by using the transfection reagent in serum-free medium. Total cellular proteins were isolated at $48 \mathrm{~h}$ after transfection. PKC $\varepsilon$ expression was monitored by reverse transcription-polymerase chain reaction (RT-PCR) and Western blot using the anti-PKCE antibody mentioned above.

\section{Reverse transcription-polymerase chain reaction}

Total RNA was isolated from 769P cells transfected with PKC $\varepsilon$ siRNA or control siRNA, or from untransfected cells using TRIzol Reagent (Invitrogen) as per the manufacturer's protocol, and subjected to reverse transcription using reverse transcriptase Premix Ex Taq (Takara, Otsu, Japan). The sequences of PKC $\varepsilon$ primers used for PCR were as follows: forward, 5'ATGGTAGTGTTCAATGGCCTTCT-3'; reverse, 5'-TCAGGGCATCAGGTCTTCAC-3'. The sequences of internal control glyceraldehyde-3-phosphate dehydrogenase (GAPDH) were as follows: forward, 5'-ATGTCGTGGAGTCTA CTGGC-3'; reverse, 5'-TGACCTTGCCCACAGCCTTG3'. PKC $\varepsilon$ was amplified by 30 cycles of denaturation at $95^{\circ} \mathrm{C}$ for $1 \mathrm{~min}$, annealing at $60^{\circ} \mathrm{C}$ for $30 \mathrm{~s}$, extension at $72^{\circ} \mathrm{C}$ for $2 \mathrm{~min}$, and final extension at $72^{\circ} \mathrm{C}$ for $8 \mathrm{~min}$. The products were resolved on a $1 \%$ agarose gel containing ethidium bromide for electropheresis.

\section{Colony formation assay}

Cell proliferation was assessed by colony formation assay. PKC $\varepsilon$ siRNA-transfected, control siRNA-transfected, and untransfected 769P cells were seeded in a 6 -well plate $\left(1 \times 10^{3}\right.$ cells/well $)$, and cultured in complete medium for 1 week. Cell colonies were then visualized by $0.25 \%$ crystal violet. After washing out the dye, colonies containing $>50$ cells were counted. The colony formation efficiency (CFE) was the ratio of the colony number to the planted cell number.

\section{Wound-healing assay}

Cell migration was evaluated by a scratched woundhealing assay on plastic plate wells. In brief, 769P cells were seeded in a 6 -well plate $\left(5 \times 10^{5}\right.$ cells/well $)$ and grew to confluence. The monolayer culture was scratched with a sterile micropipette tip to create a denuded zone (gap) of constant width and the cell debris with PBS was removed. The initial gap length and the residual gap length at 6,12 , or $24 \mathrm{~h}$ after wounding were observed under an inverted microscope (ZEISS AXIO OBSERVER Z1) and photographed. The wound area was measured by the program Image J http://rsb. info.nih.gov/ij/. The percentage of wound closure was estimated by 1 - (wound area at Tt/wound area at T0) $\times$ $100 \%$, where $\mathrm{Tt}$ is the time after wounding and T0 is the time immediately after wounding.

\section{Invasion assay}

Cell invasion was assessed using the CHEMICON cell invasion assay kit (Millipore, Billerica, MA, USA) according to the manufacturer's instructions. In brief, $300 \mu \mathrm{l}$ of warm serum-free medium was added into the interior of each insert ( $8 \mu \mathrm{m}$ pore size) to rehydrate the extracellular matrix (ECM) layer for $2 \mathrm{~h}$ at room temperature, then it was replaced with $300 \mu \mathrm{l}$ of prepared serum-free suspension of untransfected 769P cells, or cells transfected with PKC $\varepsilon$ siRNA or control siRNA (5 $\times 10^{5}$ cells $\left./ \mathrm{ml}\right) ; 500 \mu \mathrm{l}$ of medium containing $10 \%$ fetal bovine serum was added to the lower chamber of the insert. Cells were incubated at $37^{\circ} \mathrm{C}$ in a $5 \% \mathrm{CO}_{2}$ atmosphere for $24 \mathrm{~h}$. After then, non-invading cells in the interior of the inserts were gently removed with a cotton-tipped swab; invasive cells on the lower surface of the inserts were stained with the staining solution for 20 min and counted under a microscope. All experiments were performed in triplicate.

\section{Drug sensitivity assay}

At $48 \mathrm{~h}$ after siRNA transfection, transfected and untransfected cells were seeded into a 96-well plate at a density of $5 \times 10^{3}$ cells/well. After $24 \mathrm{~h}$, cells were treated with various doses of sunitinib or 5-fluorouracil (Sigma, St Louis, MO, USA) for additional $48 \mathrm{~h}$. Cell viability was measured by the MTT assay following the manufacturer's instructions. All experiments were performed in triplicate.

\section{Caspase-3 activity assay}

The activity of caspase- 3 was determined using the caspase- 3 activity kit (Beyotime, Haimen, China), based on the ability of caspase-3 to change acetyl-Asp-Glu-ValAsp p-nitroanilide (Ac-DEVD-pNA) into a yellow formazan product $\mathrm{p}$-nitroaniline (pNA) $[29,30]$. According to the manufacturer's protocol, cell lysates of transfected and untransfected 769P cells after drug treatment as described above were centrifuged at $12,000 \times g$ for 15 min at $4^{\circ} \mathrm{C}$, and protein concentrations were determined by Bradford protein assay. Cellular extracts $(30 \mu \mathrm{g})$ were 
incubated in a 96-well microtitre plate with $10 \mu \mathrm{l} \mathrm{Ac-}$ DEVD-pNA $(2 \mathrm{mM})$ for $6 \mathrm{~h}$ at $37^{\circ} \mathrm{C}$. Then caspase- 3 activity was quantified in the samples with a microplate spectrophotometer (NanoDrop 2000c, Thermo Fisher Scientific Inc., USA) by the absorbance at a wavelength of $405 \mathrm{~nm}$. All experiments were performed in triplicate.

\section{Statistical analysis}

Statistical analysis was performed using the SPSS 13.0 software. The relationship between PKCE expression and the clinicopathologic features of RCC was assessed by the Fischer's exact test. Continuous data are expressed as mean \pm standard deviation. Statistical significance was analyzed by one-way analysis of variance (ANOVA) followed by Bonferroni's post-hoc test, with values of $P<0.05$ considered statistically significant.

\section{Results}

PKC $\varepsilon$ expression in renal tissues

The expression of PKC $\varepsilon$ protein in 15 specimens of normal renal tissues and 128 specimens of RCC was detected by immunohistochemistry with an anti-PKC $\varepsilon$ monoclonal antibody. PKC $\varepsilon$ expression was weak in normal renal tissues, but strong in both cytoplasm and nuclei of RCC cells (Figure 1). The level of PKC $\varepsilon$ overexpression was significantly higher in RCC than in normal tissues $(63.3 \%$ vs. $26.7 \%, P=0.006)$. When stratified

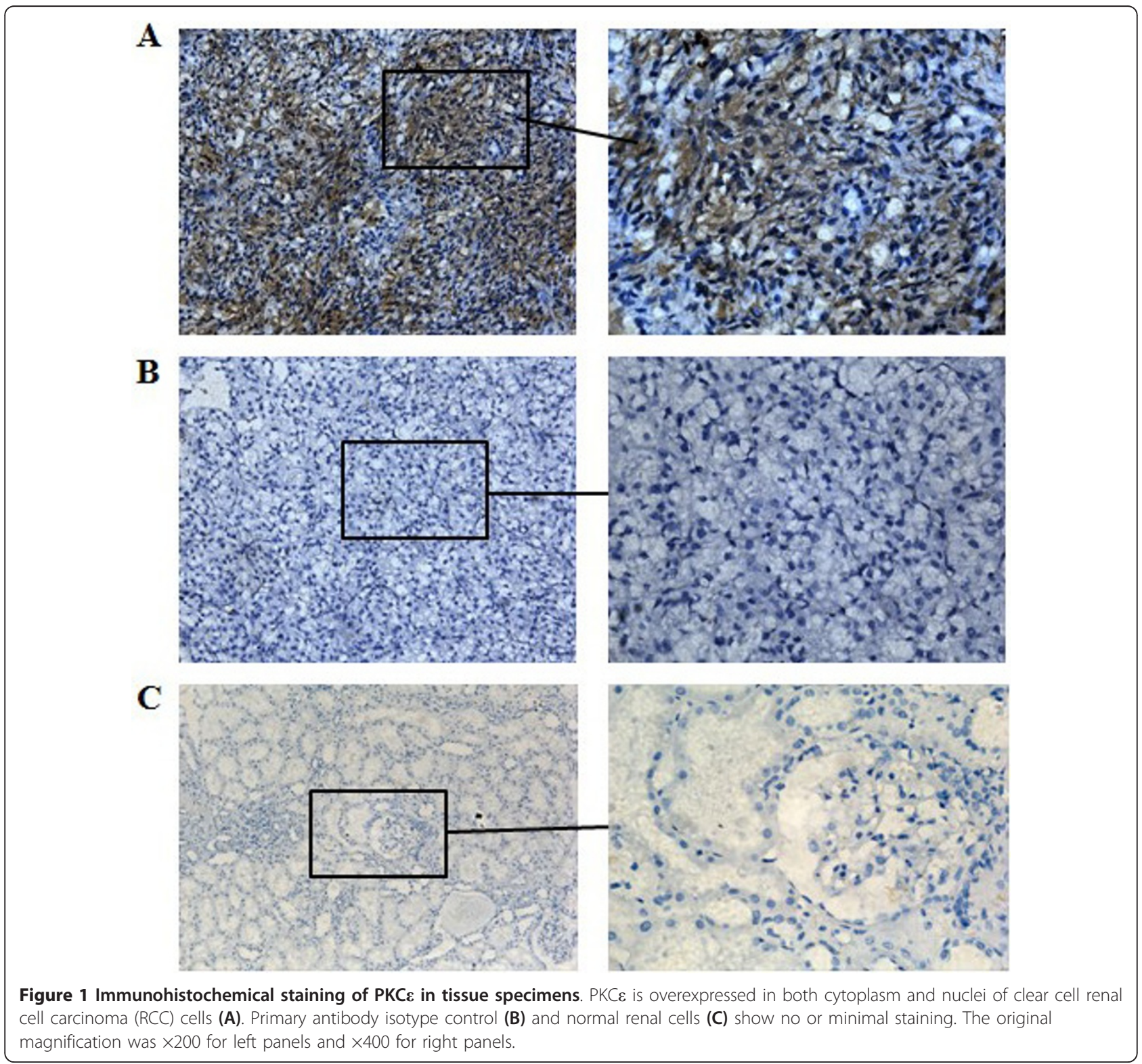


by pathologic type, no significant difference was observed among clear cell, papillary, and chromophobe RCCs $(62.0 \%$ vs. $60.0 \%$ and $80.0 \%, P=0.517)$. PKC $\varepsilon$ overexpression showed no relationship with the sex and age of patients with clear cell RCC (both $P>0.05$ ), but was related with higher $\mathrm{T}$ stage $(P<0.05)$ and higher Fuhrman grade $(P<0.01)$ (Table 1$)$.

\section{PKC $\varepsilon$ expression in renal cell cancer cell lines}

We detected the expression of PKC $\varepsilon$ in five RCC cell lines using Western blot. PKC $\varepsilon$ was expressed in all five RCC cell lines at various levels, with the maximum level in clear cell RCC cell line 769P (Figure 2A). Immunocytochemical staining showed that $\mathrm{PKC} \varepsilon$ was mainly expressed in both cytoplasm and nuclei, sometimes on the membrane, of 769P cells (Figure 2B).

\section{Effects of PKC\& on proliferation, migration, and invasion of 769P cells}

To examine the functions of $\mathrm{PKC} \varepsilon$, we knocked down PKC $\varepsilon$ by transfecting PKC $\varepsilon$ siRNA into 769P cells. The mRNA and protein expression of PKC $\varepsilon$ was significantly weaker in PKCe siRNA-transfected cells than in control siRNA-transfected cells and untransfected cells (Figure $3 \mathrm{~A}$ and $3 \mathrm{~B}$ ). The colony formation assay revealed that cell colony formation efficiency were lower in PKCe siRNA-transfected cells than in control siRNA-transfected and untransfected cells [(29.6 \pm $1.4) \%$ vs. $(60.9 \pm 1.5) \%$ and $(50.9 \pm 1.1) \%, P<0.05]$, suggesting that $\mathrm{PKC \varepsilon}$ may be important for the growth and survival of RCC cells.

The wound-healing assay also demonstrated significant cell migration inhibition in PKC $\varepsilon$ siRNA-transfected cells compared with control siRNA-transfected and untransfected cells at $24 \mathrm{~h}$ after wounding [wound

Table 1 PKC $\varepsilon$ overexpression in human clear cell renal cell carcinoma tissues

\begin{tabular}{|c|c|c|c|c|}
\hline \multirow[t]{2}{*}{ Group } & \multirow[t]{2}{*}{ Cases } & \multicolumn{2}{|c|}{ PKC $\varepsilon$ overexpression } & \multirow[t]{2}{*}{$P$ value } \\
\hline & & $(-)$ & $(+)$ & \\
\hline \multicolumn{5}{|l|}{ Sex } \\
\hline Men & 69 & 24 & 45 & 0.365 \\
\hline Women & 39 & 17 & 22 & \\
\hline \multicolumn{5}{|l|}{ Age } \\
\hline$\leq 55$ years & 43 & 16 & 27 & 0.599 \\
\hline$>55$ years & 65 & 21 & 44 & \\
\hline \multicolumn{5}{|l|}{ T stage } \\
\hline $\mathrm{T}_{1 /} \mathrm{T}_{2}$ & 89 & 38 & 51 & 0.028 \\
\hline $\mathrm{T}_{3} / \mathrm{T}_{4}$ & 19 & 3 & 16 & \\
\hline \multicolumn{5}{|c|}{ Fuhrman grade } \\
\hline $\mathrm{G}_{1} / \mathrm{G}_{2}$ & 86 & 39 & 47 & 0.002 \\
\hline $\mathrm{G}_{3} / \mathrm{G}_{4}$ & 22 & 2 & 20 & \\
\hline
\end{tabular}

$\mathrm{PKC} \varepsilon$, protein kinase $\mathrm{C}$ epsilon.

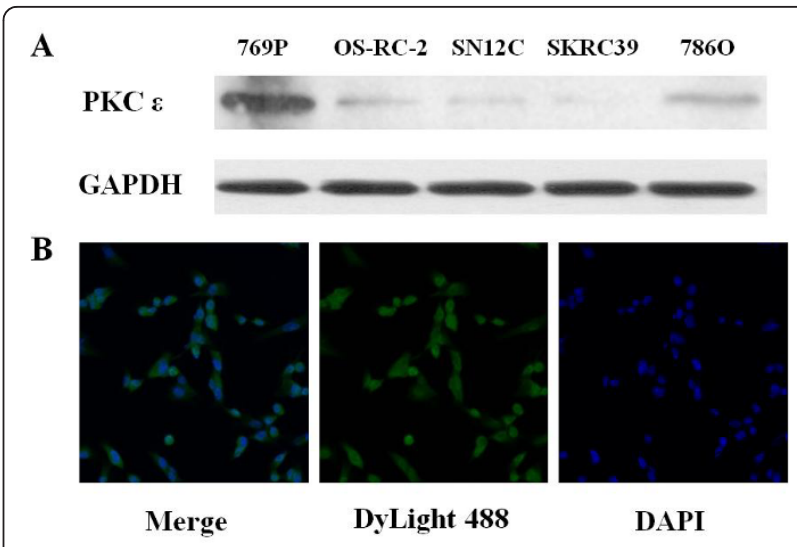

Figure 2 Expression of PKC $\varepsilon$ in renal cell carcinoma (RCC) cell lines. A. Western blot shows that PKC $\varepsilon$ is expressed in all five RCC cell lines, with the highest level in 769P cells. GAPDH is the loading control. B. Immunocytochemical staining with PKC $\varepsilon$ antibody shows that PKC $\varepsilon$ is mainly expressed in cytoplasm and nuclei of 769P cells (original magnification×200). Green fluorescence indicates PKC $\varepsilon^{-}$ positive cells, whereas blue fluorescence indicates the nuclei of the cells. The first panel is a merge image of the latter two.

closure ratio: $(42.6 \pm 5.3) \%$ vs. $(77.1 \pm 4.1) \%$ and $(87.2$ $\pm 5.5) \%, P<0.05$ ] (Figure $3 \mathrm{C}$ ). The CHEMICON cell invasion assay demonstrated that the number of invading cells was significantly decreased in PKCE siRNA group compared with control siRNA and blank control groups $(120.9 \pm 8.1$ vs. $279.0 \pm 8.3$ and $308.5 \pm 8.8, P$ $<0.01$ ) (Figure 3D). Our data implied that PKC knockdown also inhibited cell migration and invasion in vitro.

\section{Knockdown of PKC $\varepsilon$ sensitizes 769P cells to chemotherapy in vitro}

As PKCe is involved in drug resistance in some types of cancer and adjuvant chemotherapy is commonly used to treat $\mathrm{RCC}$, we tested whether PKCE is also involved in drug response of RCC cell lines. Both siRNA-transfected and untransfected 769P cells were treated with either sunitinib or 5-fluorouracil. The survival rates of 769P cells after treatment with Sunitinib and 5-fluorouracil were significantly lower in PKCE siRNA group than in control siRNA and blank control groups (all $P<0.01$ ) (Figure 4).

Caspase-3 is the final executor of apoptotic DNA damage, and its activity is a characteristic of apoptosis [10]. We next examined cell apoptosis after siRNA transfection and treatment with cytotoxic drug sunitinib or 5-fluorouracil. At $48 \mathrm{~h}$, the caspase-3 activity was significantly higher in PKCe siRNA-transfected cells, either with or without drug treatment, than in untransfected cells $(P<0.01)$ (Figure 5A), and was significantly higher in the cells underwent both siRNA transfection and 


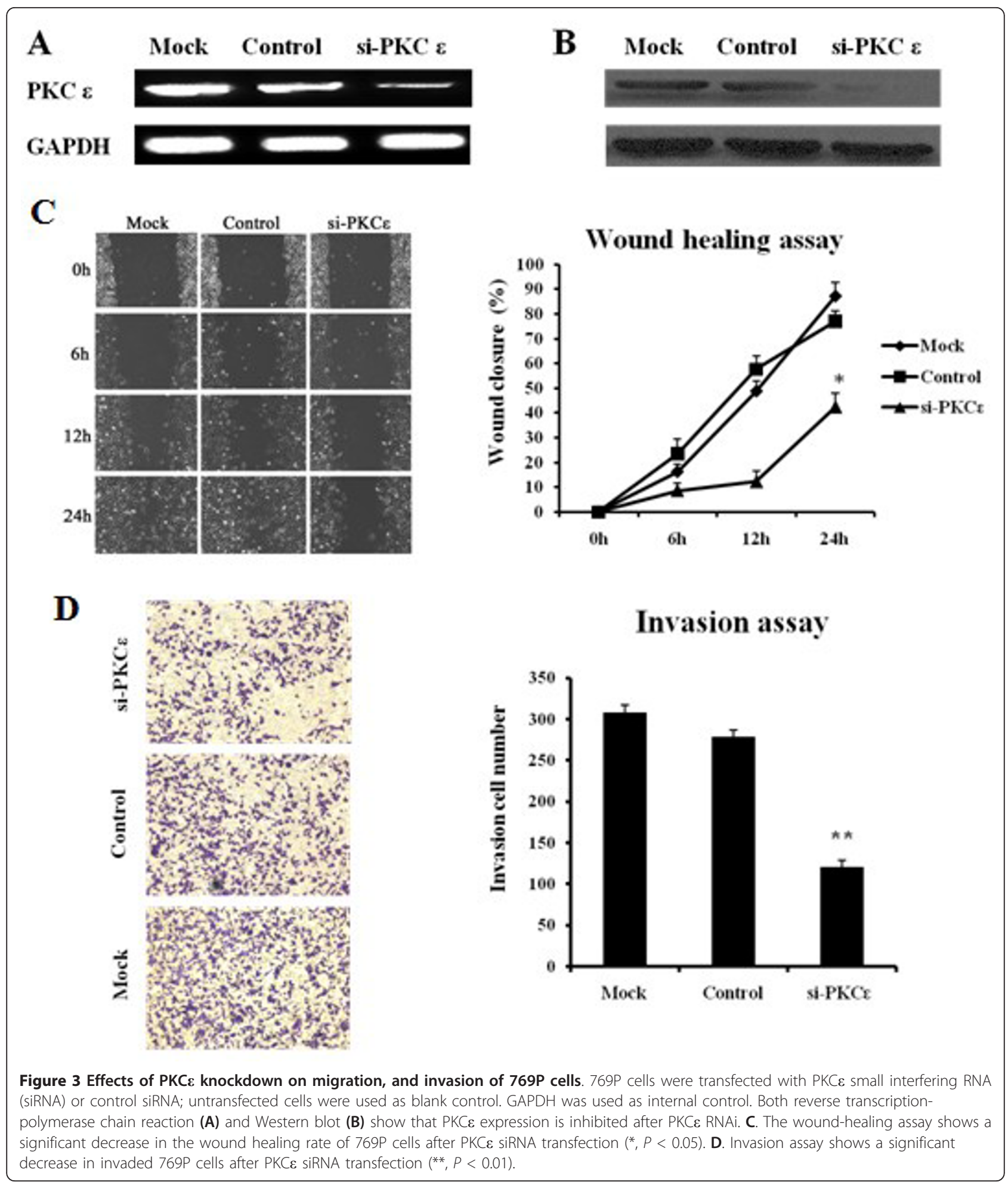




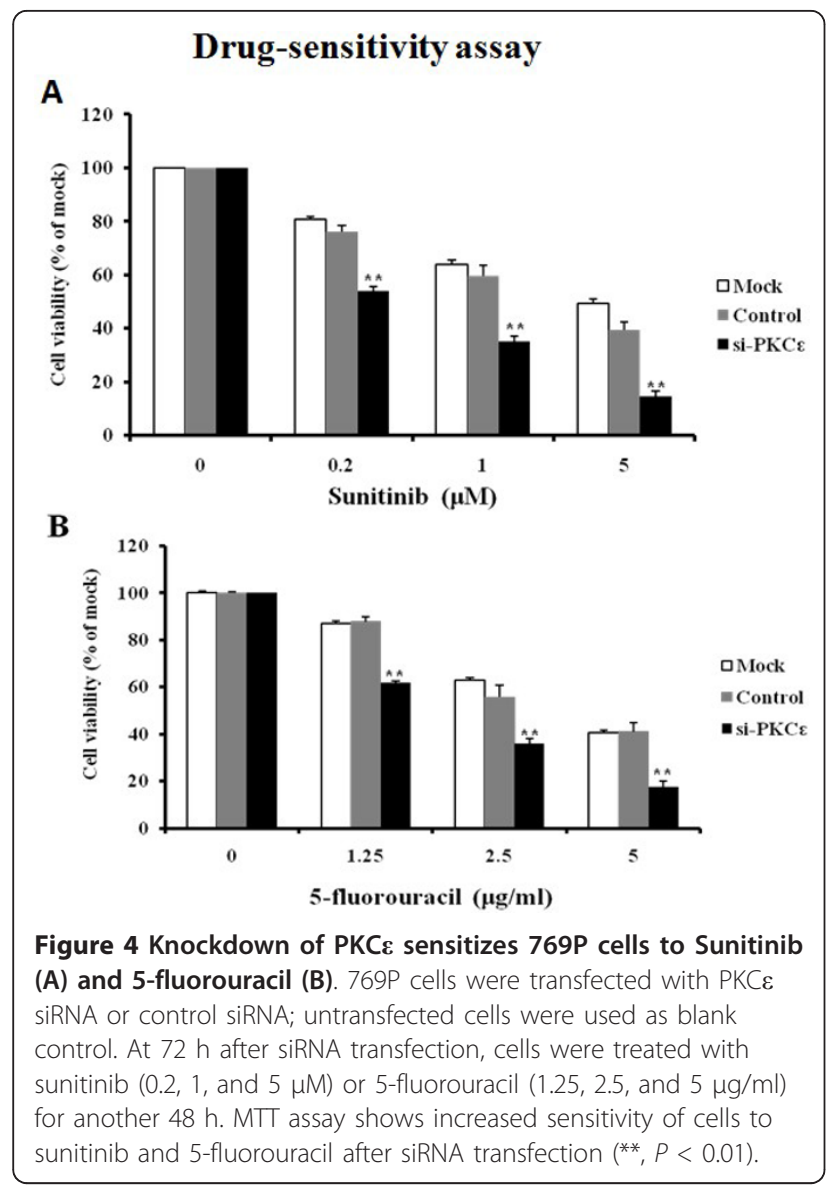

drug treatment than in those underwent only drug treatment $(P<0.05)$ (Figure $5 \mathrm{~B})$, suggesting that PKC $\varepsilon$ may contribute to the resistance of clear cell RCC cells to cytotoxic drugs.

\section{Discussion}

Increasing evidences indicate that $\mathrm{PKC} \varepsilon$ is overexpressed in various tumor tissues and functions as a transforming oncogene [14-20]. To explore the oncogenic potential of PKC $\varepsilon$, Mischak et al. [31] overexpressed PKC $\varepsilon$ in NIH 3T3 fibroblasts and observed accelerated growth of cells with $\mathrm{PKC \varepsilon}$ overexpression. In addition, tumors were developed in all mice injected with $\mathrm{PKC} \varepsilon$-overexpressing $\mathrm{NIH} 3 \mathrm{~T} 3$ cells. In the same year, Cacace et al. [32] confirmed the oncogenic role of PKC $\varepsilon$ in fibroblasts. Similarly, Perletti et al. [33] found that PKCE overexpression in colonic epithelial cells led to a metastatic phenotype, including morphological changes, increased anchorageindependent growth and tumorigenesis in a xenograft model. We also found that PKCE was overexpressed in RCC tissues as compared with that in normal renal tissues and that PKCE was closely related to higher grades of clear cell RCC. PKC $\varepsilon$ was also expressed in all five human RCC cell lines used in our study.
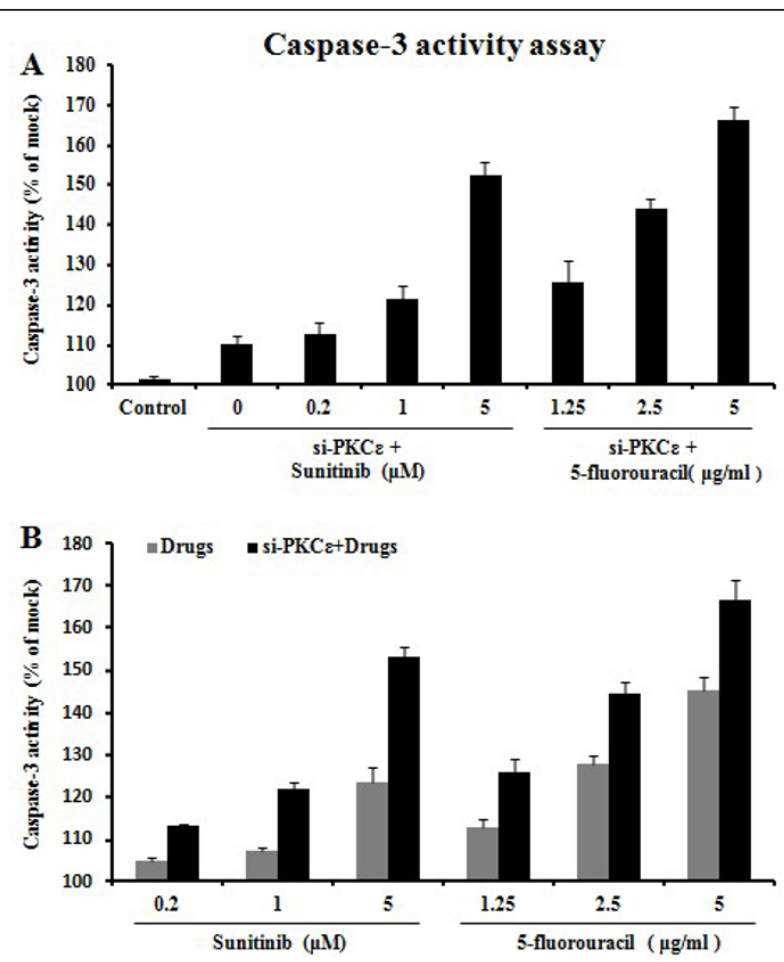

Figure 5 Changes of caspase-3 activity in 769P cells after PKC $\varepsilon$ downregulated and cytotoxic drug treatment. 769P cells were transfected with PKC $\varepsilon$ siRNA; untransfected cells were used as blank control. At $72 \mathrm{~h}$ after siRNA transfection, cells were treated with indicated doses of sunitinib or 5 -fluorouracil. Panel A shows that the caspase-3 activity was significantly higher in PKC $\varepsilon$ siRNA-transfected cells, either with or without drug treatment, than in untransfected cells $(P<0.01)$ and was higher in the cells underwent both siRNA transfection and drug treatment than in those underwent only siRNA transfection $(P<0.05)$. Panel $B$ shows that the caspase-3 activity was significantly higher in the cells underwent both siRNA transfection and drug treatment than in those underwent only drug treatment $(P<0.05)$.

PKC $\varepsilon$ has been shown to regulate many cellular processes, including cell proliferation, migration, invasion, chemo-resistance, apoptosis, and differentiation [9-12]. Multiple mechanisms are involved in $\mathrm{PKC} \varepsilon$-regulated tumorigenesis. For example, PKC $\varepsilon$ promotes cell proliferation and survival by regulating the Ras signaling pathway, which is a well characterized signaling pathway in cancer biology [10,34]. PKCE expression is related to the activation of cyclin D1 promoter, a downstream effects of Ras signaling, and to enhanced cell growth [9-11]. In addition, PKC 8 plays a role in anti-apoptotic signaling pathways through interacting with caspases and Bcl-2 family members $[35,36]$, and exerts its pro-survival effects by activating Akt/PKB $[27,37]$. These mechanisms may explain the inhibited growth of RCC cells by PKC $\varepsilon$ knockdown in our study.

Like in other cancer types, relapse and metastasis are the main causes of failure of surgical operation in 
treating clear cell RCC. Patients with RCC response to postoperative adjuvant chemotherapy at various levels and usually cannot achieve expected outcomes [3]. The phenotype of tumor metastasis presents with promotion of cell proliferation, escape from apoptosis, and dysregulation of cellular adhesion and migration. The invasion of tumor cells to surrounding tissues and spreading to distal sites rely on cell migration ability. Cell migration, a complex event, depends on the coordinated remodeling of the actin cytoskeleton, regulated assembly, and turnover of focal adhesion [11]. Interestingly, $\mathrm{PKC} \varepsilon$ contains an actin-binding domain [12] and promotes F-actin assembly in a cell-free system, indicating that $\mathrm{PKC} \varepsilon$ modulates cell migration via actin polymers. In addition, $\mathrm{PKC} \varepsilon$ has been observed to translocate to the cell membrane during the formation of focal adhesions [38] and to reverse the effect of non-signaling $\beta 1$-integrin molecules in inhibiting cell spreading [39]. PKCE-driven cell migration was shown to be mediated, at least in part, by activating downstream small Rho GTPases, especially RhoA and/or RhoC [17]. We found that silencing PKCE by RNAi decreased migration and invasion of clear cell RCC cells in vitro, suggesting that $\mathrm{PKC} \varepsilon$ may be one of the potential treatment targets for this disease. Additionally, $\mathrm{PKC} \varepsilon$ is also cleaved by caspases in response to several apoptotic stimuli including chemotherapeutic agents. $\mathrm{PKC} \varepsilon$ is a substrate for caspase- 3 as evidenced by caspase-3-caused PKCE cleavage and the inhibition of $\mathrm{PKC} \varepsilon$ cleavage by a cell permeable inhibitor of caspase-3 [40]. PKC $\varepsilon$ has been shown to regulate apoptosis mediated by either DNA damage or receptor [10]. $\mathrm{PKC} \varepsilon$ up-regulation was associated with chemoresistance of non-small cell lung cancer (NSCLC) cell lines, whereas chemosensitivity was proved in PKCE-knockdown SCLC cells [41]. In addition, PKCE was reported to mediate with induction of the drug-resistance gene P-glycoprotein in LNCaP cells [42]. In our study, PKCE knockdown enhanced the activity of pro-apoptotic gene caspase- 3 and sensitized 769P cells to chemotherapy, indicating the association between $\mathrm{PKC} \varepsilon$ and chemosensitivity of RCC.

\section{Conclusions}

Our results confirm the role of $\mathrm{PKC} \varepsilon$ as an oncogene in $\mathrm{RCC}$, especially in the subtype of clear cell, suggesting that $\mathrm{PKC} \varepsilon$ might be a potential treatment target for this disease, which warrants verification in further studies.

\section{Acknowledgements}

This work was supported by grants from the National Natural Science Foundation of China (No. 30872584, 81071760, 30772503); Guangdong Natural Science Foundation (No. 8251008901000018); Sun Yat-sen Innovative Talents Cultivation Program for Excellent Tutors (No. 80000-3126205); and
Science and Technology Planning Project of Guangdong Province, China (No. 2011B050400021, 2008B080701021).

\section{Author details}

'Department of Urology, the First Affiliated Hospital, Sun Yat-Sen University, Guangzhou (510080), China. ${ }^{2}$ Research Center for Clinical Laboratory Standard, Zhongshan Medical School, Sun Yat-sen University, Guangzhou (510080), China. ${ }^{3}$ Pulmonary disease institute, Guangzhou Chest Hospital Pulmonary Disease Institute, Guangzhou (510095), China. ${ }^{4}$ Department of Urology, Sun Yat-Sen University Cancer Center, Guangzhou (510060), China.

\section{Authors' contributions}

JTZ, JCP and CQM evaluated the immunostainings. BH have made substantial contributions to acquisition of data. XBL, SJG and ZW performed the statistical analysis. $\mathrm{BH}, \mathrm{JXC}$ and $\mathrm{SPQ}$ participated in the design of the study. $\mathrm{BH}$ and $\mathrm{KYC}$ drafted the manuscript. XPM and SPQ revised the manuscript. All authors read and approved the final manuscript.

\section{Competing interests}

The authors declare that they have no competing interests.

Received: 16 August 2011 Accepted: 28 September 2011 Published: 28 September 2011

\section{References}

1. Jemal A, Siegel R, Xu J, Ward E: Cancer statistics, 2010. CA Cancer J Clin 2010, 60:277-300.

2. Klatte T, Pantuck AJ, Kleid MD, Belldegrun AS: Understanding the natural biology of kidney cancer: implications for targeted cancer therapy. Rev Urol 2007, 9:47-56.

3. Finley DS, Pantuck AJ, Belldegrun AS: Tumor biology and prognostic factors in renal cell carcinoma. Oncologist 2011, 16:4-13.

4. Jaken S: Protein kinase C isozymes and substrates. Curr Opin Cell Biol 8(1996):168-173.

5. Newton AC: Regulation of the $A B C$ kinases by phosphorylation: protein kinase $C$ as a paradigm. Biochem J 2003, 370:361-371.

6. Parker PJ, Parkinson SJ: AGC protein kinase phosphorylation and protein kinase C. Biochem Soc Trans 2001, 29:860-863.

7. Griner EM, Kazanietz MG: Protein kinase C and other diacylglycerol effectors in cancer. Nat Rev Cancer 2007, 7:281-294.

8. Gutcher I, Webb PR, Anderson NG: The isoform-specific regulation of apoptosis by protein kinase C. Cell Mol Life Sci 2003, 60:1061-1070.

9. Gorin MA, Pan Q: Protein kinase $C \varepsilon$ : an oncogene and emerging tumor biomarker. Mol Cancer 2009, 8:9.

10. Basu A, Sivaprasad U: Protein kinase $C \varepsilon$ makes the life and death decision. Cell Signal 2007, 19:1633-1642.

11. Akita Y: Protein kinase Cepsilon: multiple roles in the function of and signaling mediated by, the cytoskeleton. FEBS J 2008, 275:3995-4004

12. Akita Y: Protein kinase $C \varepsilon(\mathrm{PKC} \varepsilon)$ : its unique structure and function. J Biochem 2002, 132:847-852.

13. Totoń E, Ignatowicz E, Skrzeczkowska K, Rybczyńska M: Protein kinase $C \varepsilon$ as a cancer marker and target for anticancer therapy. Pharmacol Rep 2011, 63:19-29.

14. Varga A, Czifra G, Tallai B, Németh T, Kovács I, Kovács L, Bíró T: Tumor grade-dependent alterations in the protein kinase $\mathrm{C}$ isoform pattern in urinary bladder carcinomas. Eur Urol 2004, 46:462-465.

15. Wu D, Foreman TL, Gregory CW, Mcjilton MA, Wescott GG, Ford OH, Alvey RF, Mohler JL, Terrian DM: Protein kinase cepsilon has the potential to advance the recurrence of human prostate cancer. Cancer Res 2002, 62:2423-2429.

16. Pan Q, Bao LW, Kleer CG, Sabel MS, Griffith KA, Teknos TN, Merajver SD: Protein kinase $\mathrm{C}$ epsilon is a predictive biomarker of aggressive breast cancer and a validated target for RNA interference anticancer therapy. Cancer Res 2005, 65:8366-8371.

17. Pan Q, Bao LW, Teknos TN, Merajver SD: Targeted disruption of protein kinase $C$ epsilon reduces cell invasion and motility through inactivation of RhoA and RhoC GTPases in head and neck squamous cell carcinoma. Cancer Res 2006, 66:9379-9384.

18. Bae KM, Wang H, Jiang G, Chen MG, Lu L, Xiao L: Protein kinase C epsilon is overexpressed in primary human non-small cell lung cancers and functionally required for proliferation of non-small cell lung 
cancer cells in a p21/Cip1-dependent manner. Cancer Res 2007, 67:6053-6063.

19. Brenner W, Benzing F, Gudejko-Thiel J, Fischer R, Färber G, Hengstler JG, Seliger B, Thüroff JW: Regulation of beta1 integrin expression by PKCepsilon in renal cancer cells. Int J Oncol 2004, 25:1157-1163.

20. Engers R, Mrzyk S, Springer E, Fabbro D, Weissgerber G, Gernharz CD, Gabbert HE: Protein kinase $C$ in human renal cell carcinomas: role in invasion and differential isoenzyme expression. Br J Cancer 2000, 82:1063-1069.

21. Green FL, Page DL, Fleming ID, et al: AJCC Cancer Staging Manual. Springer: New York; 62002.

22. Fuhrman SA, Lasky LC, Limas C: Prognostic significance of morphologic parameters in renal cell carcinoma. Am J Surg Pathol 1982, 6:655-663.

23. Yamada S, Yanamoto S, Kawasaki G, Rokutanda S, Yonezawa H, Kawakita A, Nemoto TK: Overexpression of CRKII increases migration and invasive potential in oral squamous cell carcinoma. Cancer Letters 2011, 303:84-91.

24. Fu L, Qin YR, Xie D, Chow HY, Ngai SM, Kwong DL, Li Y, Guan XY: Identification of alpha-actinin 4 and $67 \mathrm{kDa}$ laminin receptor as stagespecific markers in esophageal cancer via proteomic approaches. Cancer 2007, 110:2672-2681

25. Guo S, Mao X, Chen J, Huang B, Jin C, Xu Z, Qiu S: Overexpression of Pim1 in bladder cancer. J Exp Clin Cancer Res 2010, 29:161.

26. Pedram A, Razandi M, Wallace DC, Levin ER: Functional estrogen receptors in the mitochondria of breast cancer cells. Mol Biol Cell 2006, 17:2125-37.

27. Lu D, Huang J, Basu A: Protein kinase C epsilon activates protein kinase B/Akt via DNA-PK to protect against tumor necrosis factor-alphainduced cell death. J Biol Chem 2006, 281:22799-22807.

28. Hu B, Shen B, Su Y, Geard CR, Balajee AS: Protein kinase $C \varepsilon$ is involved in ionizing radiation induced bystander response in human cells. Int $J$ Biochem Cell Biol 2009, 41:2413-2421.

29. Wei $X$, Juan ZX, Min FX, Nan C, Hua ZX, Qing FZ, Zheng L: Recombinant immunotoxin anti-c-Met/PE38KDEL inhibits proliferation and promotes apoptosis of gastric cancer cells. J Exp Clin Cancer Res 2011, 30:67.

30. Zhao CQ, Liu Da, Li Hai, Jiang LS, Dai LY: Interleukin-1b enhances the effect of serum deprivation on rat annular cell apoptosis. Apoptosis 2007, 12:2155-2161.

31. Mischak H, Goodnight JA, Kolch W, Martiny-Baron G, Schaechtle C, Kazanietz MG, Blumberg PM, Pierce JH, Mushinski JF: Overexpression of protein kinase C-delta and -epsilon in NIH $3 \mathrm{~T} 3$ cells induces opposite effects on growth, morphology, anchorage dependence, and tumorigenicity. J Biol Chem 1993, 268:6090-6096.

32. Cacace AM, Guadagno SN, Krauss RS, Fabbro D, Weinstein IB: The epsilon isoform of protein kinase $C$ is an oncogene when overexpressed in rat fibroblasts. Oncogene 1993, 8:2095-2104.

33. Perletti GP, Folini M, Lin HC, Mischak H, Piccinini F, Tashjian AH Jr: Overexpression of protein kinase $\mathrm{C}$ epsilon is oncogenic in rat colonic epithelial cells. Oncogene 1996, 12:847-854.

34. Hamilton M, Liao J, Cathcart MK, Wolfman A: Constitutive association of c$\mathrm{N}$-Ras with c-Raf-1 and protein kinase $\mathrm{C} \varepsilon$ in latent signaling modules. J Biol Chem 2001, 276:29079-29090.

35. Sivaprasad U, Shankar E, Basu A: Protein kinase C-epsilon protects MCF-7 cells from TNF-mediated cell death by inhibiting Bax translocation. Cell Death Differ 2007, 14:851-860

36. Mcjilton MA, Van Sikes C, Wescott GG: Protein kinase Cepsilon interacts with Bax and promotes survival of human prostate cancer cells. Oncogene 2003, 22:7958-7968.

37. Wu D, Thakore CU, Wescott GG, McCubrey JA, Terrian DM: Integrin signaling links protein kinase Cepsilon to the protein kinase B/Akt survival pathway in recurrent prostate cancer cells. Oncogene 2004, 23:8659-8672.

38. Hernandez RM, Wescott GG, Mayhew MW, Mcjilton MA, Terrian DM: Biochemical and morphogenic effects of the interaction between protein kinase C-epsilon and actin in vitro and in cultured NIH3T3 cells. J Cell Biochem 2001, 83:532-546.

39. Berrier AL, Mastrangelo AM, Downward J, Ginsberg M, LaFlamme SE: Activated R-ras. Rac1, PI 3-kinase and PKCepsilon can each restore cell spreading inhibited by isolated integrin beta1 cytoplasmic domains. J Cell Biol 2000, 151:1549-1560.

40. Hoppe J, Hoppe V, Schafer R: Selective degradation of the PKC-epsilon isoform during cell death in AKR-2B fibroblasts. Exp Cell Res 2001, 266:64-73.
41. Mayne GC, Murray AW: Evidence that protein kinase Cepsilon mediates phorbol ester inhibition of calphostin C- and tumor necrosis factoralpha-induced apoptosis in U937 histiocytic lymphoma cells. J Biol Chem 1998, 273:24115-24121.

42. Flescher $\mathrm{E}$, Rotem R: Protein kinase $\mathrm{C}$ epsilon mediates the induction of P-glycoprotein in LNCaP prostate carcinoma cells. Cell Signal 2002, 14:37-43.

doi:10.1186/1756-9966-30-88

Cite this article as: Huang et al.: The expression and role of protein kinase C (PKC) epsilon in clear cell renal cell carcinoma. Journal of Experimental \& Clinical Cancer Research 2011 30:88.

\section{Submit your next manuscript to BioMed Central and take full advantage of:}

- Convenient online submission

- Thorough peer review

- No space constraints or color figure charges

- Immediate publication on acceptance

- Inclusion in PubMed, CAS, Scopus and Google Scholar

- Research which is freely available for redistribution

Submit your manuscript at www biomedcentral com/submit
C Biomed Central 